PRINT ISSN 1119-8362

Electronic ISSN 1119-8362
Full-text Available Online at

https://www.ajol.info/index.php/jasem

http://ww.bioline.org.br/ja
J. Appl. Sci. Environ. Manage.

Vol. 25 (8) 1497-1503 August 2021

\title{
Isolation of Ganoderma lucidum (Curtis) P. Karst. From the Wild in Lagos through Tissue Culture Techniques and Cultivation on Sawdust of Six Nigerian Hardwoods
}

\author{
*ADONGBEDE, EM; ${ }^{2}$ ATOYEBI, AF \\ *Department of Botany, University of Lagos, Akoka, Yaba, Lagos, Nigeria \\ "Corresponding Author Email: eadongbede@unilag.edu.ng; ajibolaaramide52@gmail.com
}

\begin{abstract}
Cultivation of Ganoderma lucidum (Curtis) P. Karst, a medicinal mushroom known for antioxidant, antitumor, anti-inflammatory, and immunomodulatory activities is not practiced in Nigeria. Tree species used for cultivation in Asia, America and Europe are not available in Nigeria. The present study investigated indigenous hardwoods and their supplementation with rice and wheat bran as substrates for its cultivation. Six hardwoods (Mansonia altissima (A Chev.) A Chev., Avecennia germinans (L.) L, Lophira alata Banks ex Gaertn., Triplochiton scleoxylon K. Schum, Uapaca guineensis Mull. Arg, Nauclea diderrichii (De Wild. \& Th. Dur.) Merrill) were investigated as potential growth substrates and potentially improve biological efficiency. The mushroom was collected from the wild and identification confirmed by amplifying the ribosomal DNA-ITS fragment with ITS1 and ITS4 primers. Tissue culture of the mushroom collected from the wild was initiated successfully with modified malt extract agar and grain spawn developed from it. The substrates were incubated after inoculation with grain spawn at room temperature for 30-60 days. Substrates were given cold treatment for 7 days to induce fructification which was achieved with 9-10h/day regime and daily watering. There was full mycelial ramification of all substrates by the mushroom. Fruit bodies were harvested from all substrates but Lophira alata. The highest yield $(308.76 \pm 5.81 \mathrm{~g} / \mathrm{kg}$ ) was recorded with Mansonia altissima (Biological Efficiency- $31.42 \pm 4.55 \%$ ) and the least yield $(31.45 \pm 5.44 \mathrm{~g} / \mathrm{kg}$ ) was recorded in Nauclea diderrichii (B.E- 5.25 $\pm 0.58 \%$ ). The substrates with wheat bran performed significantly better than rice bran supplemented substrates. Commercial cultivation of native G. lucidum in Nigeria is possible with local agricultural wastes.
\end{abstract}

DOI: $\underline{\text { https://dx.doi.org/10.4314/jasem.v25i8.33 }}$

Copyright: Copyright (C) 2021 Adongbede and Ayotebi. This is an open access article distributed under the Creative Commons Attribution License (CCL), which permits unrestricted use, distribution, and reproduction in any medium, provided the original work is properly cited.

Dates: Received: 10 May 2021; Revised: 28 June 2021; Accepted: 01 July 2021

Keywords: Hardwood, Sawdust, Mushroom cultivation, Reishi, Medicinal mushroom

The mushroom and polypore- Ganoderma lucidum (Curtis) P. Karst. is of immense value medicinally and economically worldwide. It has a worldwide distribution, found both in tropical and temperate ecosystems in Asia, Africa, America, and Europe. It is currently sold as supplements or nutraceuticals in various forms like teas, coffees, tablets, and capsules generating income for the developed and developing Countries. Ganoderma lucidum (Curtis) P. Karst, belongs to the family Ganodermataceae which is a large family of polypores with seven accepted genera viz- Amauroderma, Foraminispora, Furtadoa, Haddowia, Humphreya and Polyporopsis. The members of the family Ganodermataceae are cosmopolitan basidiomycetes (Cao and Yuan, 2013). The genus Ganoderma was proven by Karsten as far back as 1881 with the name Ganoderma lucidum (Curtis) P. Karst. as the type species (Moncalvo and Ryvarden, 1997). Ganoderma species can be found in tropical and temperate regions, Asia, America, Europe, and Africa. The sporophores or fruiting bodies of the mushroom can be seen growing from living or dead trunks and branches of trees. They grow as facultative parasites that continue to live as saprophytes on decaying wood (Hapuarachchi, et al., 2018; Turner, 1981). Ganoderma used traditional as a medicinal mushroom for over two thousand years in Asian countries for sustaining energy and longevity (Hapuarachchi, et al., 2018). The efficacy of Ganoderma lucidum as a drug documented in ancient manuscripts (Wasser, et al., 2005). The varieties of fruiting bodies produced by Ganoderma species vary from laccate ones with shiny upper surfaces to nonlaccate ones with dull upper surfaces (Smith and Sivasithamparam, 2003). Ganoderma species are not typically classified as edible mushroom because they have a bitter taste, are texturally hard not having the fleshy texture characteristic of true edible mushrooms (Jong and Birmingham, 1992). Species of this genus cause white rot of hard woods by disintegrating or degrading lignin, cellulose, and other related cell wall polysaccharides (Adaskaveg, et al., 1991) Ganoderma are of great economic importance because of their medicinal properties and pathogenicity to tree crops. The macro-fungus is a white rot fungus that cause white rot of tree species (Dai, et al., 2007). Ganoderma 
are now classified as functional foods because of their proven efficacy in preventing and treating immunological diseases and are widely used as dietary supplements in China, Japan, North and South America and even in Africa (De Silva, et al., 2013; Wang, et al., 2012). Typically, Ganoderma is called "Reishi" (divine mushroom) or "Lingzhi" in China. Ganoderma lucidum (Curtis) P. Karst. a woody polypore -(Basidiomycota) seen as the "herb of spiritual potency" or mushroom of immortality in Chinese and Japanese traditional herbal practice (Sliva, 2006). Research and development of useful products from Ganoderma is the new rage because of the enormous potential of poroid mushrooms in biotechnology and medical practice (Hapuarachchi, et al., 2017). The efficacy of Ganoderma species as functional food buttressed by the fact that over 1,000 Ganoderma health food products already certified by the Chinese government (Chen, et al., 2016). The normal practice with consumption of mushrooms involves collection from the wild and Ganoderma species are no different. In ancient times, Ganoderma typically collected from the wild and consumed by only the royals and wealthy people (Chen, et al., 2016). In the present time a vast proportion of consumed Ganoderma are from cultivated stock and not from the wild. Attempts at cultivation of Ganoderma started as far back as 1937 but successful cultivation only came in in 1969 with spore separation cultivation method (Wasser, 2011). Traditional cultivation of Ganoderma was based on log inoculation without sterilization. This has since changed and artificial cultivation now involves the use of grains, sawdust, wood logs, cotton seed husk, sunflower seed hull, corn cobs, cork residues, olive oil press cakes, wheat straw or other agricultural wastes from farm crops (Wasser, 2011; Chang and Buswell, 1999; Gregori and Pohleven, 2014; Gonzalez-Matutes, et al., 2002; Erkel, 2009). The most popular method previously used for cultivation of Ganoderma lucidum and still in use is the log cultivation. Now recognizing the importance of preserving forest trees, sawdust cultivation is encouraged as it also solves the problem of wastes generated by sawmills involved in wood processing. There is the need to breed new Ganoderma strains all over the world to enhance development of strains with higher yield, introduction of new substrates and substrate combinations, new spawn preparation techniques with the sole aim of increasing the productivity of the mushroom culture. The cultivation of Ganoderma lucidum has the potential to solve problems by using up wastes from sawmills, supplies residues to be consumed as animal feed, soil conditioners, mushroom re-cultivation, and a bioremediation tool (Zhou, et al., 2011). Medicinal mushrooms are new to Nigeria, but potentials exist for new herbal products and its medicinal value can be made popular and made available through cultivation locally. It is important to introduce Ganoderma lucidum into the Nigerian society because of the health benefits and economic success that can be got from its products. China and other Asian Countries are currently generating income from importing nutraceuticals from Ganoderma to Africa and other Countries. Ganoderma products can be seen on shelves in pharmacies and supermarkets in Nigeria. The mushroom/polypore used for this study was got from the wild in Nigeria and identification confirmed with molecular means. The mushroom is therefore indigenous to Nigeria and can therefore grow on our native tree species as seen in the wild. The hardwood tree species commonly found in Nigeria from the wood processing plants are used as potential substrates for the medicinal mushroom Ganoderma. The main aim of the current study was to isolate, identify, wildly collected $G$. lucidum through tissue culture and molecular techniques and find appropriate growth substrate for its commercial cultivation in Nigeria by assessing the efficacy of sawdust of six tree species readily available in Nigeria.

\section{MATERIALS AND METHOD}

Collection of Mushroom Specimens and Sawdust of Hardwoods: Research into the best practices needed for the isolation, domestication, and cultivation of the wild medicinal mushroom -Ganoderma lucidum was conducted at the laboratory of the Mushroom Science and Fungal Biotechnology Unit of the Botany Department, University of Lagos, Lagos Nigeria. Mushroom specimens were collected from the Lagoon front University of Lagos Akoka, Yaba, Lagos, Nigeria (GPS- location -N 006 30' 80" E $003^{\circ} 24^{\prime} 31^{\prime \prime}$ ) from the base of a dead Albizia zygia tree (Figure 1).

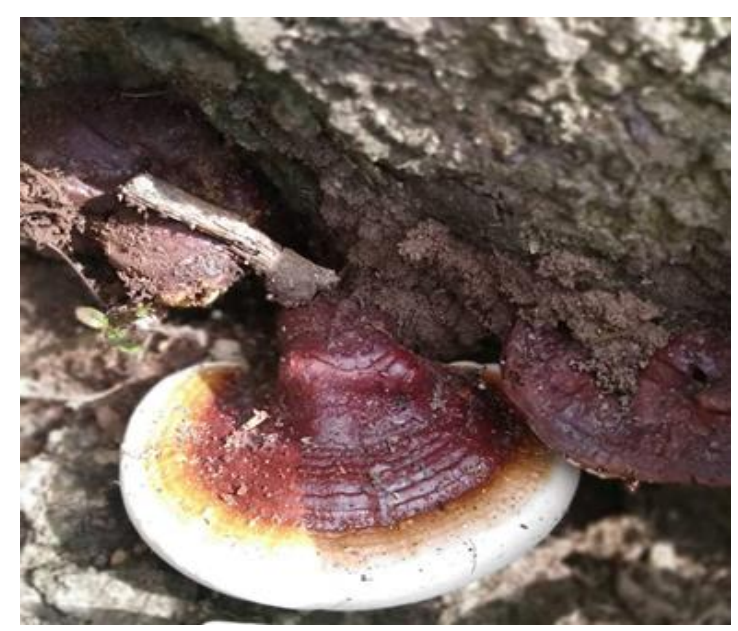

Plate 1: Ganoderma lucidum on a dead Albizia zygia tree at the Lagoon Front University of Lagos, Akoka Yaba Lagos. 
Phenotypic observations were made following methods described by Wang, et al. (2009). The microscopic features were viewed under the light microscope after mounting with $5 \% \mathrm{KOH}$ solution. The wild polypore mushroom was identified to species level using standard manuals (De Kesel, 2011; Moncalvo and Ryvarden, 1997; Wang, et al., 2009; Moncalvo, 2000). Identification was further confirmed using molecular means.

DNA Extraction: Identification of the wild polypore was confirmed by first extracting genomic DNA from the tissues of the wild mushroom. The rDNA extraction was conducted with Norgen Plant/Fungi DNA isolation kit following manufacturer's instruction.

PCR Amplification and Sequencing: After extraction, the ribosomal DNA templates was used for PCR amplification with the primers ITS1 forward, 5'-TCC GTA GGT GAA CCT GCG G-3' and ITS 4 reverse 5'TCC TCC GCT TAT TGA TAT GC-3'. The polymerase chain reaction (PCR) of the rDNA templates was conducted with the Norgen's 2 x PCR master mix with a final volume of $20 \mu \mathrm{l}$. The master mix was made up of $2 \mu \mathrm{l}$ each of the forward and reverse primers -ITS-1F and ITS-4R respectively, 10 $\mu l$ of the master mix and $8 \mu$ l of DNA free water. Amplification was conducted in a thermocycler with a heated lid, started at an initial denaturation temperature of $94^{\circ} \mathrm{C}$ for 3 minutes followed by a 30 cycles series of denaturation at $94^{\circ} \mathrm{C}$ for 1 minute. This was followed by the annealing process which was done at for 1 minute at $56^{\circ} \mathrm{C}$ and then elongation for 1 minute at $72^{\circ} \mathrm{C}$. The amplification was concluded with a final extension for 10 minutes at $72^{\circ} \mathrm{C}$. The quality of PCR products was further checked with a nanodrop spectrophotometer and cleaned after electrophoresis in a $1 \%$ agarose gel tank with standard TBE buffer. The gel run images were viewed after staining with the SYBR® Green dye and images captured in a UV chamber. The amplified PCR products were cleaned using the PCR purification kit from Norgen Biotek Corp. ON, Canada. The sequence editing was done with the Sequencher 5.4.6 software and involved trimming and assembling of sequences to get contigs. The contigs were aligned with the multiple sequence alignment program-the Clustal tool in the Sequencher software. The identity of the wild polypore was confirmed with the megablast tool available on the NCBI GenBank (Martin and Rygiewicz, 2005; Zhang, et al. 2000)

The blast results from the GenBank confirmed that the wild polypore is Ganoderma lucidum with a $99.32 \%$ identity match to Ganoderma lucidum isolate CAW 23, E-value was 0.0 with a GenBank Accession Number - GQ249886.1. A second megablast result recorded an identity match of $99.15 \%$ to Ganoderma lucidum voucher CWN01740 and a GenBank Accession Number MK940282 and an E-value of 0.0.

The sawdust of six hardwoods (with their Yoruba names)- "Ofun" (Mansonia altissima), Ogbun (Avecennia germinans), Ekki (Lophira alata), Obeche (Triplochiton scleroxylon), abo emido (Uapaca guineensis), Opepe- Nauclea diderrichii (Table 1) used were collected from a sawmill (a wood processing facility for diverse types of hard and soft woods) at the Makoko area of Yaba, Shomolu local government area, Lagos State.

Table 1: Identity of Test Hard Woods

\begin{tabular}{llll}
\hline Scientific Name of Test Native Woods & Common Name & Local Name & Family \\
\hline Mansonia altissima (A Chev.) A Chev. & $\begin{array}{l}\text { Mansonia, Africa } \\
\text { black walnut }\end{array}$ & Ofun & Malvaceae Juss. \\
& Black mangrove & Ogbun & Acanthaceae \\
Avicennia germinans (L.) L & Red iron wood & Ekki & Ochnaceae \\
Lophira alata Banks ex Gaertn. & African white wood & Obeche & Malvaceae \\
Triplochiton scleroxylon K. Schum. & Red cedar & Abo emido & Phyllanthaceae \\
Uapaca guineensis Mull. Arg. & Opepe, Billinga & Opepe & Rubiaceae \\
Nauclea diderrichii (De Wild. \& Th. Dur.) Merrill & & & \\
\hline
\end{tabular}

Tissue culture and spawn development of Wild Strain of Ganoderma lucidum: Tissue cultures of G. lucidum collected from the wild was prepared on modified malt extract agar (MEA) medium by excising sterile tissues from the basidiocarp of the mushroom following a modification of methods described in Stamets and Chilton (1983). The mycelial from the MEA medium on a Petri plate was used for spawn development. The wild strain was kept at room temperature $\left(24^{\circ}-30^{\circ} \mathrm{C}\right)$ on $2 \%$ potato dextrose agar (PDA) and sub-cultured every three weeks. Cultures were kept in preservative medium in the culture bank of the Mushroom Science and Fungal Biotechnology Unit of the Botany Department, University of Lagos, Lagos, Nigeria.

Spawn Development: The spawn type used for artificial cultivation of the wild G. lucidum was grain spawn. The grain spawn was developed following a modification of the method used by Pire, et al. (2001). 


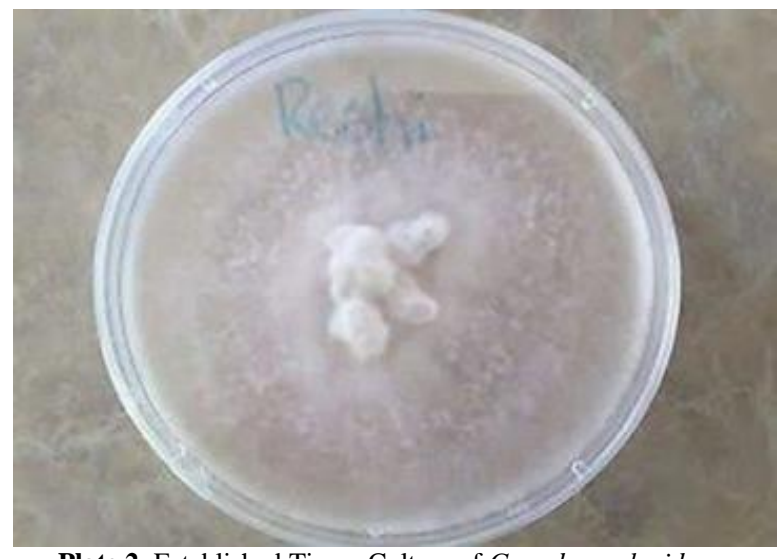

Plate 2: Established Tissue Culture of Ganoderma lucidum growing on modified MEA medium

The spawn was developed from grains of Sorghum bicolor bought from Oyingbo market Yaba, Lagos Nigeria. The grains were soaked, parboiled, drained and $1 \% \mathrm{w} / \mathrm{w}$ of calcium carbonate added and properly mixed. The grains were left to dry and packed in jam jars (glass bottles) to $3 / 4$ of their volume and sterilized at $121^{0}, 2 \mathrm{psi}$ for 45 minutes. After cooling, the sterilized grains were aseptically inoculated with mycelial cultures developed from tissue cultures. All inoculated mother spawn bottles were incubated at room temperature in an airconditioned room. The mycelia development/spawn run was checked until complete colonization of the bottles was achieved. Contaminated bottles were removed and sub-culturing into freshly prepared grains was done to multiply or increase grain spawns. Mycelial colonization time was recorded from day of inoculation to complete colonization.

Sawdust Substrate Development:

The wild G. lucidum strain was cultivated on sawdust of six native trees (hardwoods) - Mansonia altissima, Avicennia germinans, Lophira alata, Triplochiton scleroxylon, Uapaca guineensis and Nauclea diderrichii. The sawdust of these hardwoods was independently used to prepare eighteen different substrate combinations with four replicates each. The substrates were initially soaked in water individually to soften them and drained. Supplementation with rice bran and wheat bran was done as treatment options while the type of sawdust used served as different experimental blocks. The sawdust and supplements were mixed in a 9:1 ratio based on their dry weight to a total of $2 \mathrm{~kg}$ per bag. All substrates were also treated with $\mathrm{MgSO}_{4}$ and $\mathrm{CaCO}_{3}$. The moisture content of the substrates was adjusted to $60-65 \%$ with the help of a moisture analyzer and the palm squeeze test method before sterilization. The substrate bags were autoclaved at $121^{\circ} \mathrm{C}$ for $2 \mathrm{hrs}$. After cooling sterilized bags were inoculated in the laminar air flow cabinet. After inoculation, the substrate bags were placed in the dark/incubation room found at the Mushroom Biotechnology laboratory at the University of Lagos Central Research Laboratory facility. The room was regularly disinfected with pine sol solution and air purifier. The temperature in the incubation room was recorded regularly and varied between $24-30^{\circ} \mathrm{C}$. The mycelial development on the substrate bags was checked daily until complete colonization was seen and noted. Contaminated bags were checked for and at once removed if noticed.

Initiation of fructification: Fructification was initiated after full colonization and ramification of the substrate bags by the mushroom. The bags were moved to the fruiting room within the lab and fructification induced by introduction of light, increased flow of air and watering. The room was kept humid at a relative humidity of $75-90 \%$, kept with an aspersion spray regime which takes place for 3 minutes every $3 \mathrm{~h}$. The onset of primordia formation shows the start of fructification. Fruiting bodies were harvested when the caps became completely red, and the white margin had disappeared. The total yield for each treatment was recorded for each flush for a period 60-70days.

Determination of yield and Biological Efficiency: The colonization period for the spawn and substrates, number of days to primordia formation and first harvest period were documented.

Biological Efficiency (BE) was calculated according to (Royse, 1985) using the following equation.

$$
B E=(\%) \frac{\mathrm{FM}(\mathrm{g})}{\mathrm{DM}(\mathrm{g})} \times 100
$$

Where FW = fresh weight of harvested Mushrooms; $\mathrm{DM}=$ dry matter content of substrate used

Statistical Analysis: The experimental design was a randomized block design with a total of eighteen treatments and three variables, each treatment was replicated four times. The treatments were the types of hardwood only, hard woods supplemented with rice bran and hard woods supplanted with wheat bran. Statistical analysis was performed with the SPSS 
Statistics 24 software. Duncan's multiple range test was used to conduct tests of simple effects that were statistically significant at $5 \%$ level of significance.

\section{RESULTS AND DISCUSSION}

Effect of Sawdust Type and Supplementation on G. lucidum Colonization period (Spawn run): The growth and subsequent yield of G. lucidum varied with the substrate/wood type and supplements added. The Mansonia altissima wood substrate recorded the least time to complete colonization as the mushroom completely ramified the substrate in 29 days (Table 2). The addition of supplements further enhanced the growth of the mushrooms as the period taken for full colonization was reduced to 20 days with the wheat bran and 22 days with the rice bran (Table 2). There was significant difference caused by supplementation with both rice and wheat bran (Table 2).
Supplementation improved the growth and ramification of the sawdust by the mushroom mycelial. Primordia emergence of the cultivated mushroom was first seen on Mansonia altissima substrates in the wheat bran supplemented treatment after 29 days (Table 3). The emergence of primordia in the substrates of Triplochiton scleroxylon occurred after 50 days (Table 3 ).

The primordia initiation followed the trend of colonization as the best substrate was M. altissima and supplementation improved or shortened period to emergence of primordia (Table 3). The number of days to first harvest varied among the types of wood sawdust used. Mushrooms were first harvested from the Mansonii altissima substrates. Supplementation did not significantly affect the number of days to harvest within the same wood type treatment.

Table 2: Effect of Different Native tree species and supplementation on spawn run period (Days) for G. lucidum.

\begin{tabular}{llll}
\hline \multirow{2}{*}{ Native Wood Species } & \multicolumn{4}{l}{ Growth Substrates } \\
\cline { 2 - 4 } & $\begin{array}{l}\text { Sawdust } \\
\text { Wheat bran }\end{array}$ & $\begin{array}{l}\text { Sawdust } \\
\text { Rice Bran }\end{array}$ & $\begin{array}{l}\text { Sawdust } \\
\text { Only }\end{array}$ \\
\hline Mansonia altissima (A Chev.) A Chev. & $20.30 \pm 2.20^{\mathrm{a}}$ & $22.14 \pm 3.28^{\mathrm{a}}$ & $28.60 \pm 1.05^{\mathrm{b}}$ \\
Avicennia germinans (L.) L & $25.81 \pm 2.55^{\mathrm{ab}}$ & $26.92 \pm 3.00^{\mathrm{ab}}$ & $30.55 \pm 1.26^{\mathrm{b}}$ \\
Lophira alata Banks ex Gaertn. & $23.22 \pm 3.04^{\mathrm{a}}$ & $23.07 \pm 3.42^{\mathrm{a}}$ & $31.30 \pm 2.05^{\mathrm{b}}$ \\
Triplochiton scleroxylon K. Schum. & $24.74 \pm 2.86^{\mathrm{ab}}$ & $25.68 \pm 2.55^{\mathrm{ab}}$ & $36.21 \pm 1.14^{\mathrm{bc}}$ \\
Uapaca guineensis Mull. Arg. & $22.67 \pm 3.22^{\mathrm{a}}$ & $25.41 \pm 2.75^{\mathrm{bc}}$ & $33.80 \pm 1.50^{\mathrm{b}}$ \\
Nauclea diderrichii (De Wild. \& Th. Dur.) Merrill & $30.09 \pm 4.05^{\mathrm{b}}$ & $31.19 \pm 5.28^{\mathrm{b}}$ & $40.35 \pm 1.36^{\mathrm{c}}$ \\
\hline
\end{tabular}

*Each value is the Mean - \pm SE of four replicates. Means with different superscripts letters are significantly different $(P<0.05)$

Table 3: Effect of Different Hardwoods on Primordia Initiation (Number of Days from Spawning) of Ganoderma lucidum

\begin{tabular}{llll}
\hline \multirow{2}{*}{ Native Wood Species } & \multicolumn{4}{l}{\begin{tabular}{l} 
Growth Substrates \\
\cline { 2 - 4 }
\end{tabular}} & $\begin{array}{l}\text { Sawdust } \\
\text { Wheat bran }\end{array}$ & $\begin{array}{l}\text { Sawdust } \\
\text { Rice Bran }\end{array}$ & $\begin{array}{l}\text { Sawdust } \\
\text { Only }\end{array}$ \\
\hline Mansonia altissima (A Chev.) A Chev. & $29.30 \pm 0.61^{\mathrm{a}}$ & $31.60 \pm 0.52^{\mathrm{a}}$ & $38.10 \pm 0.35^{\mathrm{b}}$ \\
Avicennia germinans (L.) L & $36.52 \pm 1.25^{\mathrm{b}}$ & $38.46 \pm 1.40^{\mathrm{b}}$ & $43.15 \pm 1.04^{\mathrm{bc}}$ \\
Lophira alata Banks ex Gaertn. & $37.70 \pm 2.04^{\mathrm{b}}$ & $36.10 \pm 1.91^{\mathrm{b}}$ & $43.22 \pm 0.28^{\mathrm{bc}}$ \\
Triplochiton scleroxylon K. Schum. & $40.20 \pm 1.72^{\mathrm{b}}$ & $42.90 \pm 2.25^{\mathrm{bc}}$ & $50.50 \pm 0.88^{\mathrm{c}}$ \\
Uapaca guineensis Mull. Arg. & $34.55 \pm 0.55^{\mathrm{ba}}$ & $34.60 \pm 0.49^{\mathrm{ba}}$ & $40.40 \pm 1.44^{\mathrm{b}}$ \\
Nauclea diderrichii (De Wild. \& Th. Dur.) Merrill & $44.20 \pm 2.84^{\mathrm{bc}}$ & $43.50 \pm 1.86^{\mathrm{bc}}$ & $45.70 \pm 0.71^{\mathrm{bc}}$ \\
\hline
\end{tabular}

*Each value is the Mean - \pm SE of four replicates. Means with different superscripts letters are significantly different $(P<0.05)$

Table 4: Effect of Sawdust Type and Supplementation on Number of Days to First Harvest (Days)

\begin{tabular}{llll}
\hline & Native Wood Species & \multicolumn{3}{l}{ Growth Substrates } \\
\cline { 2 - 4 } & $\begin{array}{l}\text { Sawdust }+ \\
\text { Wheat bran }\end{array}$ & Rice bran & \multicolumn{2}{l}{$\begin{array}{l}\text { Sawdust } \\
\text { Only }\end{array}$} \\
\hline Mansonia altissima (A Chev.) A Chev. & $35.48 \pm 3.05^{\mathrm{a}}$ & $37.91 \pm 2.38^{\mathrm{a}}$ & $44.45 \pm 1.06^{\mathrm{a}}$ \\
Avicennia germinans (L.) L & $47.50 \pm 1.92^{\mathrm{a}}$ & $48.80 \pm 3.03^{\mathrm{a}}$ & $48 \pm 1.65^{\mathrm{a}}$ \\
Lophira alata Banks ex Gaertn. & $45.90 \pm 2.18^{\mathrm{a}}$ & $44.34 \pm 2.01^{\mathrm{a}}$ & $49.70 \pm 1.30^{\mathrm{ab}}$ \\
Triplochiton scleroxylon K. Schum. & $52.70 \pm 1.09^{\mathrm{b}}$ & $54.52 \pm 2.17^{\mathrm{b}}$ & $58.10 \pm 1.41^{\mathrm{b}}$ \\
Uapaca guineensis Mull. Arg. & $43.11 \pm 2.21^{\mathrm{a}}$ & $46.20 \pm 1.88^{\mathrm{a}}$ & $54.61 \pm 0.95^{\mathrm{b}}$ \\
Nauclea diderrichii (De Wild. \& Th. Dur.) Merrill & $60.33 \pm 2.51^{\mathrm{b}}$ & $61 \pm 1.73^{\mathrm{b}}$ & $59 \pm 1.03^{\mathrm{b}}$ \\
\hline
\end{tabular}

${ }^{*}$ Each value is the Mean - \pm SE of four replicates. Means with different superscripts letters are significantly different $(P<0.05)$ 


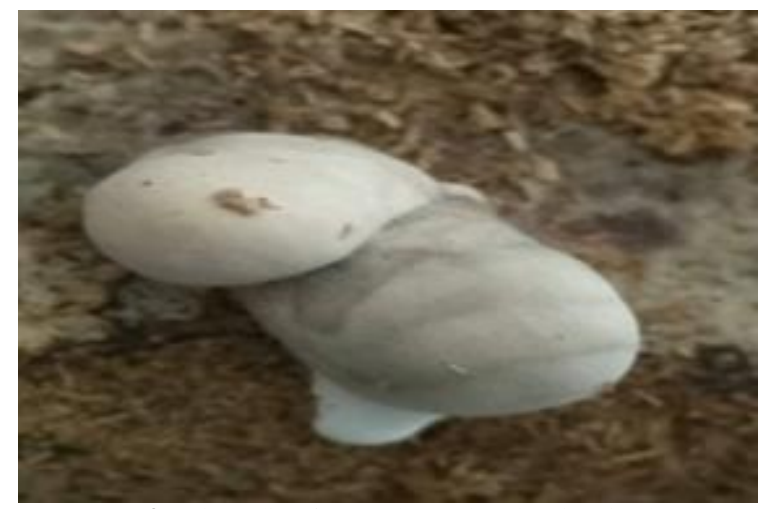

Plate 3: Primordia of Ganoderma lucidum in Rice bran Supplemented Substrate of Mansonia altissima

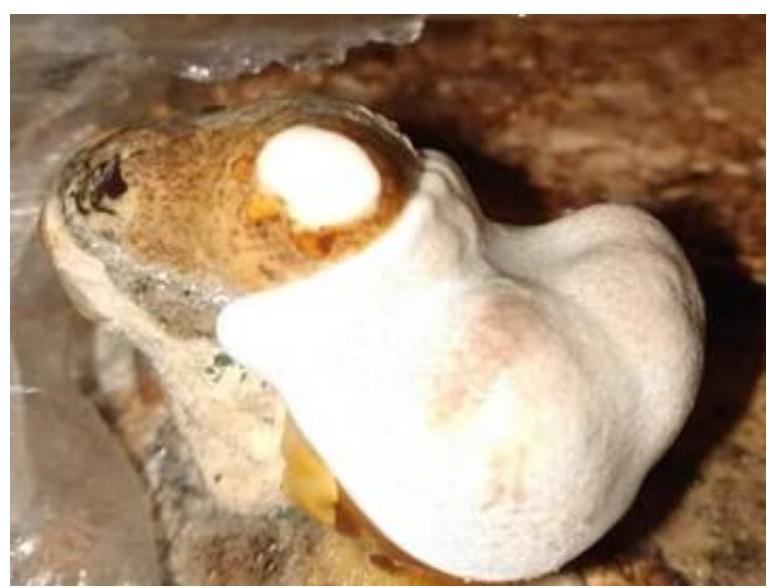

Plate 4: Primordium of Ganoderma lucidum in Wheat bran Supplemented Substrate of Mansonii altissima.

Effect of Local Hardwoods and Substrate Supplementation on yield of Ganoderma lucidum: Ganoderma lucidum performed best with the sawdust of the hardwood Mansonia altissima recording the highest yield in its substrate $(308.76 \mathrm{~g} / \mathrm{kg}$ ) (Table 5) with the wheat bran supplement. The yield from the wheat bran supplemented substrate of M. altissima was significantly higher that the yield recorded in the rice bran supplemented substrate (Table 5). The yield of the mushroom in the rice bran supplemented substrate was not significantly different from the yield of the wheat bran supplemented substrate with Uapaca guineensis (Table 5). The least yield by the mushroom among all the wood species evaluated was recorded with the sawdust of the tree crop-Nauclea diderrichii $(31.34 \mathrm{~g} / \mathrm{kg})$. Supplementation affected yield positively as supplemented substrates produced significantly higher yields (Table 5). Wheat bran proved to be a better supplement for the cultivation of G. lucidum with most hardwoods assessed as yields were significantly higher with wheat bran. The biological efficiency of the mushroom varied with the type of wood and supplementation as seen with the yield (Table 5). The highest biological efficiency $(31.34 \%)$ was recorded with the wheat bran substrate of Mansonia altissima and least was in the substrate of Nauclea diderrichii (3.40\%) (Table 6). Supplementation did not improve the biological efficiency of the mushroom in $N$. diderrichii substrate (Table 6). The addition of supplements significantly improved the yield and biological efficiency of $G$. lucidum in the other hard woods evaluated (Table 6). The best substrate for the cultivation of G. lucidum among the hard woods evaluated is that of Mansonia altissima. The sawdust of the hardwood Uapaca guineensis and that of Lophira alata showed promise as potential substrates with biological efficiency of $21.25 \%$ and $21.92 \%$ respectively with wheat supplementation.

Table 5: Effect of Six Native Hard woods on yield of G. lucidum species (Fresh Weight g/kg)

\begin{tabular}{llll}
\hline \multirow{2}{*}{ Native Wood Species } & \multicolumn{4}{l}{ Growth Substrates } & \\
\cline { 2 - 4 } & $\begin{array}{l}\text { Sawdust } \\
\text { Wheat bran }\end{array}$ & $\begin{array}{l}\text { Sawdust } \\
\text { Rice Bran }\end{array}$ & Sawdust only \\
\hline Mansonia altissima (A Chev.) A Chev. & $308.76 \pm 5.81^{\mathrm{a}}$ & $252.42 \pm 6.50^{\mathrm{b}}$ & $179.65 \pm 4.09^{\mathrm{d}}$ \\
Avicennia germinans (L.) L & $191.96 \pm 8.02^{\mathrm{d}}$ & $137.44 \pm 5.74^{\mathrm{f}}$ & $93.12 \pm 6.11^{\mathrm{i}}$ \\
Lophira alata Banks ex Gaertn. & $218.07 \pm 9.01^{\mathrm{c}}$ & $170.59 \pm 11.28^{\mathrm{e}}$ & $127.00 \pm 8.52^{\mathrm{g}}$ \\
Triplochiton scleroxylon K. Schum. & $118.77 \pm 8.85^{\mathrm{h}}$ & $83.58 \pm 6.51^{\mathrm{j}}$ & $56.11 \pm 4.22^{\mathrm{1}}$ \\
Uapaca guineensis Mull. Arg. & $254.83 \pm 10.04^{\mathrm{c}}$ & $212.71 \pm 9.89^{\mathrm{e}}$ & $118.41 \pm 6.05^{\mathrm{i}}$ \\
Nauclea diderrichii (De Wild. \& Th. Dur.) Merrill & $51.30 \pm 8.71^{\mathrm{m}}$ & $40.74 \pm 9.28^{\mathrm{n}}$ & $31.45 \pm 5.44^{\circ}$ \\
\hline
\end{tabular}

*Each value is the Mean - \pm SE of four replicates. Means with different superscripts letters are significantly different $(P<0.05)$

Table 6: Effect of different native hardwoods and supplementation on biological efficiency of G. lucidum (Percentage- \%)

\begin{tabular}{llll}
\hline \multirow{2}{*}{ Native Wood Species } & \multicolumn{3}{l}{ Growth Substrates } \\
\cline { 2 - 4 } & $\begin{array}{l}\text { Sawdust } \\
\text { Wheat bran }\end{array}$ & Sawdust & Rice Bran \\
& $+\begin{array}{l}\text { Sawdust } \\
\text { Only }\end{array}$ \\
\hline Mansonia altissima (A Chev.) A Chev. & $31.42 \pm 4.55^{\mathrm{a}}$ & $28.34 \pm 5.09^{\mathrm{b}}$ & $18.04 \pm 3.11^{\mathrm{c}}$ \\
Avicennia germinans (L.) L & $17.79 \pm 5.09^{\mathrm{c}}$ & $13.79 \pm 3.32^{\mathrm{e}}$ & $9.34 \pm 1.92^{\mathrm{f}}$ \\
Lophira alata Banks ex Gaertn. & $21.92 \pm 6.21^{\mathrm{c}}$ & $17.13 \pm 4.45^{\mathrm{cd}}$ & $12.75 \pm 2.16^{\mathrm{d}}$ \\
Triplochiton scleroxylon K. Schum. & $11.92 \pm 3.82^{\mathrm{e}}$ & $8.38 \pm 2.11^{\mathrm{f}}$ & $5.63 \pm 0.91^{\mathrm{f}}$ \\
Uapaca guineensis Mull. Arg. & $21.25 \pm 3.15^{\mathrm{c}}$ & $17.71 \pm 4.02^{\mathrm{c}}$ & $9.88 \pm 1.05^{\mathrm{f}}$ \\
Nauclea diderrichii (De Wild. \& Th. Dur.) Merrill & $4.25 \pm 0.84^{\mathrm{fg}}$ & $3.40 \pm 0.41^{\mathrm{g}}$ & $5.25 \pm 0.58^{\mathrm{g}}$ \\
\hline
\end{tabular}

*Each value is the Mean \pm SE of four replicates. Means with different superscripts letters are significantly different $(P<0.05)$ 
The present study shows that indigenous medicinal mushrooms collected from the wild can be domesticated using tissue culture techniques instead of harvesting spores from the mushrooms for propagation. The practice of harvesting spores is filled with risk of heavy contamination as there is no way of excluding contaminants from the spores. There must be series of sub-culturing before pure culture isolates can be achieved and this time consuming and very laborious. Tissue culture laboratories can be set with the aim of producing viable pure culture isolates of wild cultivable and economically viable mushrooms. Wild edible and medicinal mushrooms can, therefore, be domesticated for sustainable development (Thawthong, et al., 2014). There are expensive products from Ganoderma lucidum sold in the shops as nutraceuticals or food supplements. The successful cultivation of this medicinal mushroom with locally sourced sawdust is a start towards the development of biotechnological products and drugs by harnessing the potentials of this extremely useful mushroom. Substrate type and composition affected the yield of the mushroom as expected as there was variation in the vigor, ease of colonization, primordia formation, yield, and biological efficiency of the mushroom $G$. lucidum (Tables 2, 3, 4, 5 and 6). Domestication of wild mushrooms have the potentials of improving the yield, nutrient status, and morphological appearance of the mushrooms for commercial purposes (Herawati, et al., 2016).

The colonization time for G. lucidum for the sawdust of hardwoods evaluated varied between 20-60 days. Earlier reports show that G. lucidum successfully colonized sawdust of rubber tree (Hevea brasiliensis) and Melia azedarach (Ceylon mahogany) within a period of 27 and 23days respectively (Jeewanthi, et al., 2017), like results obtained in the present study. $G$. lucidum however showed a faster colonization rate with sawdust of the wood Swietenia mahagoni supplemented with rice and wheat bran (9 and 6 days respectively) in earlier research (Roy, et al., 2015). The mushroom therefore differs in its ability to colonize different woods and other lignocellulosic substrates. Gurung, et al. (2012), recorded a period of 35 days for full colonization of Shorea robusta substrate supplemented with gram flour, wheat bran, rice bran and corn flour, which is comparable to data obtained in the present study with the substrate Mansonia altissima supplemented with wheat bran (Table 2). Sawdust alone is not recommended for the cultivation of G. lucidum as supplementation with wheat and rice bran improved yield and biological efficiency significantly in most woods evaluated. According to (Han, et al., 1981) supplements enhance or stimulates growth of mushrooms in preferred substrates. However extreme use of supplementation may reduce the effects of substrates on mushroom production (Moonmoon, et al., 2011). The biological efficiency of the least productive wood in this study is comparable to the yield got from the studies on other hard woods from other localities like Bangladesh where biological efficiency varied from $7.6 \%$ to $3.6 \%$ for sawdust of the woods Swietenia mahogoni and Dipterocarpur turbinatus respectively (Roy, et al. 2015). Ganoderma lucidum is a medicinal mushroom, whose efficacy has been proven. The medicinal mushroom currently cultivated with sole aim of producing biomass and bioactive compounds for the pharmaceutical industry (Kaur, et al., 2015). Current work on the domestication of wild cultivars of this polypore in the Mushroom Science and Fungal biotechnology Unit at the Botany Department University of Lagos, is ongoing. The nutritional, medicinal values, and the best practices for cultivation of indigenous Ganoderma lucidum is being investigated.

Conclusion: Ganoderma lucidum was successfully isolated from the wild using tissue culture techniques and cultivated on locally available and cheap agricultural wastes. Indigenous woods from Nigeria are high yielding substrates for cultivation of the poroid mushroom. The demand for this medicinal mushroom can be met using locally available resources. The supplementation with wheat bran with the wood Mansonia altissima gave the best yield, the sawdust of Avicennia germinans and Uapaca guineensis showed potentials as high yielding substrates.

\section{REFERENCES}

Adaskaveg, JE; Blanchette, RA; Gilbertson. RL (1991). Decay of date plam wood by white rot and brown rot fungi. Canadian Journal of Botany 69: 615-629.

Cao, Y; Yuan, HS (2013). Ganoderma nutabile sp, nov, from southwestern China based on morphological and molecular data. Mycological Progress 12: 121-126.

Chang, ST; Buswell, JA (1999). Ganoderma lucidum (Curt. Fr.) P. Karst. (Aphyllophoromycetideae) A mushrooming medicinal mushroom. International Journal of Medicinal Mushrooms 1: 139-146.

Chen, RY; Kang, J; Du GH (2016). Construction of the qualitycontrol system of Ganoderma products. Edible and Medicinal Mushrooms 24 (6): 339344. 
Dai, YC; Cui, BK; Yuan, HS; Li, BD (2007). Pathogenic wood-decaying fungi in China. Forest Pathology 37: 105-120.

De Kesel, A (2011). Provisional macroscopic key to the edible mushrooms of tropical Afica 100+ taxa from the Zambezian and Sudanian region. MycoAfrica 4 (1): 1-9.

De Silva, DD; Rapior, S; Sudarman, E; Stadler, M ; $\mathrm{Xu}, \mathrm{J}$; Alias, SA; Hyde, KD (2013). Bioactive metabolites from macrofungi: ethnopharmacology, biological activities and chemistry. Fungal Diversity 62: 1-40.

Erkel, EI (2009). The effect of different substrate mediums on yield of Ganoderma lucidum (Fr.) Karst. . Journal of Food Agriculture and Environment 7: 841-844.

Gonzalez-Matutes, R; Figlas, D; Devalis, R; Delmastro, S; Curvetto, NR (2002). Sunflower Seed Hulls As A Main Nutrient Source For Cultivating Ganoderma lucidum. Micologia Aplicada International 14 (2): 1-6.

Gregori, A; Pohleven, A (2014). Cultivation of three medicinal mushroom species on olive press cakes containing substrates. Acta Agriculture Solvonica 103: 49-54.

Gurung, OK; Budathoki, U; Parajuli, G (2012). Effect of different substrates on the production of Ganoderma lucidum (Curt. Fr.) Karst. Our Nature 10: 191-198.

Han, YI; Ueng, WJ; Chen, LC; Chang, ST (1981). Physiology and ecology of Lentinus edodes (Berk) Sing. Mushroom Science 11: 623-658.

Hapuarachchi, KK; Cheng, CR; Wen, TC; Jeewon, R; Kakumyan, P (2017). Mycosphere Essays 20: Therapeutic potential of Ganoderma species: Insights into its use as traditional medicine. Mycosphere 8 (10): 1653-1694.

Hapuarachchi, KK; Elkhateeb, WA; Karunarathna, SC; Cheng, CR; Bandara, AR; Kakumyan, P; Hyde, KD; Daba, GM; Wen, TC (2018). Current status of global Ganoderma cultivation, products, industry and market. Mycosphere 9 (5): 1025 1052.

Herawati, E; Arung, ET; Amirta, R (2016). Domestication and Nutrient Analysis of Schizophyllum commune, Alternative Natural
Food Sources in East Kalimantan. Agriculture and Agricultural Science Procedia 9: 291-296.

Jeewanthi, LA; Ratnayake, MN; Rajapakse, P (2017). Growth. and Yield of Reishi Mushroom [Ganoderma lucidum (Curtis) P. Karst] in Different Sawdust Substrates. Journal of Food and Agriculture 10 (1\&2): 8-16.

Jong, JC; Birmingham, JM (1992). Medicinal Benefits of the mushroom Ganoderma. Advances in Applied Microbiology 37: 101-134.

Kaur, H; Sharma, S; Khanna, PK; Kapoor, S (2015). Evaluation of Ganoderma lucidum strains for the production of bioactive components and their potential use as antimicrobial agents. Journal of Applied and Natural Science 7 (1): 298-303.

Martin, KJ; Rygiewicz, PT (2005). Fungal-Specific PCR primers developed for analysis of the ITS region of environmental DNA extracts. BMC Microbiol 5: 28.

Moncalvo, JM (2000). Systematics of Ganoderma. In: Ganoderma Diseases of Perennial Crops, Flood, P; Bridge, D; Holderness, M (Eds.) 23-45p. Wallingford: CABI Publishing.

Moncalvo, JM; Ryvarden, L (1997). A nomenclatural study of the Ganodermataceae Donk. Fungi Flora 10: 1-114.

Moonmoon, M; Shelly, NJ; Khan, A; Uddin, N; Hossain, K; Tania, M; Ahmed, S (2011). Effects of different levels of wheat bran, rice bran and maize powder supplementation with sawdust on the production of shiitake mushroom (Lentinus edodes (Berk.) Singer). Saudi Journal of Biological Sciences 18: 323-328.

Pire, DG; Wright, JE; Alberto, E (2001). Cultivation of Shiitake Using Sawduts from Widely Available Local Woods in Argentina. Micologia Aplicada Internacional 13 (2): 87-91.

Roy, S; Jahan, MAA; Das, KK Munshi, SK; Noor R (2015). Artificial cultivation of Ganoderma lucidum (Reishi medicinal mushroom) using different sawdust substrates. American Journal of Biosciences 3: 178-182.

Royse, DJ (1985). Effect of spawn run time and substrate nutrition on yield and size of the Shiitake mushroom. Mycologia 77: 756-762. 
Sliva, D (2006). Ganoderma lucidum in cancer research. Leukemia Research 30: 767-768.

Smith, BJ; Sivasithamparam, K (2003). Morphological studies of Ganoderma (Ganodermataceae) from the Australian and Pacific regions. Australasian Systematic Botany 16: 487-503.

Stamets, P; Chilton, JS (1983). The Mushroom Cultivator. A practical guide to growing mushrooms at home. Olympia, Washington: Agarikon Press.

Thawthong, A; Karunarathna, S; Thongklang, N; Chukeatirote, E; Kakumyan, P; Chamyuang, S; Rizal, LM et al. (2014). Discovering and Domesticating Wild Tropical Cultivable Mushrooms. Chiang Mai J. Sci. 41 (4): 731-764.

Turner, PD (1981). Oil Palm Diseases and Disorders. Oxford: Oxford University Press.

Wang, DM; Wu, SH; Su, CH; Peng, JT; Shih, YH; Chen, LC (2009). Ganoderma multipileum, the correct name for 'G. lucidum' in tropical Asia. Botanical Studies 50 (4): 451-458.
Wang, XC; Xi, RJ; Li, Y; Wang, DM; Yao, YJ (2012). The Species Identity of the Widely Cultivated Ganoderma, 'G. lucidum' (Ling-Zhi in China. PLoS One 7 (7): e40857.

Wasser, SP (2011). Current findings, future trends and unsolved problems in studies of medicinal mushrooms. Applied Microbiology and Biotechnology 89: 1323-1332.

Wasser, SP; Coates, P; Blackman, M; Cragg, G; Levine, M; Moss, J; White, J (2005). Reishi or Lingzhi (Ganoderma lucidum). Encyclopedia of Dietary Supplements. New York: Marcel Dekker.

Zhang, Z; Schwartz, S; Wagner, L; Miller, W (2000). A Greedy Algorithm for Aligning DNA Sequences. J. Comput. Biol. 7: 203-214.

Zhou, XW; Su, KQ; Zhang, YM (2011). Applied modern biotechnology for cultivation of Ganoderma and development of their products. Applied Microbiology and Biotechnology 93: 941-963. 